\title{
Buying Voters: Money and Political Transaction in Legislative Elections.
}

\author{
M.Iqbal Fardian
}

Researcher at Historica Institute

cak.iqbal.fardian@gmail.com

\begin{abstract}
Political transaction has become a common phenomenon that accompanies elections. It does not only occur in countries with well-established democratic systems, but also in developing nations. Academic engagement with the concept of democracy increasingly explores its links to the chaotic commodification of electors' votes. Political transactions can trigger several problems, such as political structures, citizenship awareness, or cultural relations issues that form a democratic structure of the country. Political transactions are processes of negotiation that take place between elites. This paper explores the contestation of social positions to gain electors' votes in the context of the legislative election conducted in Banyuwangi. The strategies used by legislative candidates to obtain votes through transactional relationships demonstrates the various actors involved in general elections. First, the researcher argues that democratization has transformed the sacred position of the elites, especially the religious elite. Second, the complexity of relations between elites presents the position of a broker, which emphasizes the character of democracy in Indonesia, which is marked by issues of clientelism. Thus, it is essential to observe Indonesia's political praxis from the institutional practice point of view and its social problems that distort democratic values.
\end{abstract}

Keywords: Clientelism, Transaction Cost Politic, Money Politics

Copyright $\odot 2021$ by Author(s)

This work is licensed under a Creative Commons Attribution-ShareAlike 4.0 International License. All writings published in this journal are personal views of the authors and do not represent the views of this journal and the author's affiliated institutions.

\section{HOW TO CITE:}

Fardian, M Iqbal. "Buying Voters: Money and Political Transaction in Legislative Elections" (2021) l:1 Contemporary Sociological Issues 56-70.

Submitted :October 26, 2020

Revised :December 21, 2020
Accepted

Publish
: January 2, 2021

: February 5, 2021 


\section{INTRODUCTION}

Indonesia's democratization process is marked by political reforms that took place since the fall of the New Order regime in 1998, known as the Reform Era. During this era, the basic idea developed that was a common desire to make a total correction of the social and political life that characterized the New Order regime that was conceptualized as deviating from the real democratic state conception. The reform euphoria was construed by opening up opportunities for people's participation in general elections. This is not to say that political processes did not occur in the New Order era. However, these processes were restricted due to the simplification of political parties. As such, in the post-Suharto era, there was opportunity emerged for the establishment of political parties to participate in democratic elections. The year 1999 has come to be known as the first general election in the reform era, representing the emergence of a multi-party system in Indonesia.

Unfortunately, the democratization process, characterized by the multi-party political system, has led to the practice of money politics. This has become a common phenomenon that has since accompanied Indonesian elections ${ }^{1}$. As such, elections were nothing more than a public festival used to ask for various necessities or even money by the legislative candidates. From the political dimension, the praxis of political transaction destroys the essence of democracy. However, the way Indonesian citizens understand democracy continues to be an essential part of mapping the direction of social development.

The high-handed transactional political praxis, which can be seen through money politics, caused a costly democracy. Within this, civil society involvement cannot be separated from the entanglement of the voice of commodification. Money politics occurs both among grassroots or voter groups who receive a small amount of money, and the elite community who receive considerable amounts of money, or even projects. In this context, the culture of clientalism is considered a determinant of the practice of money politics in many developing countries that have democratic parties ${ }^{2}$. This clientelism relationship is an interesting subject to study as the pattern and mechanism that is often seen as a determinant of the emergence of money politics and even corruption.

In this paper, the author demonstrates the clientelism relationship and practice of money politics that occurred in the 2019 General Election in Glenmore, Banyuwangi. The Glenmore District represented how the power of traditional politics dealt with the issue of vote commodification. This research analyzes practical politics and observes how sociological dimensions form the electors' social character. Therefore, it is crucial

\footnotetext{
${ }^{1}$ M. Faishal Aminuddin dan Natasha Hassan Attamimi, "From Retail to Grocery: Money Politics in 2014 Indonesian Legislative Election," Politik Indonesia: Indonesian Political Science Review 4, no. 1 (2019): 99-120, https://doi.org/10.15294/ipsr.v4il.12609.

2 Burhanuddin Muhtadi, "Politik Uang Dan Dinamika Elektoral Di Indonesia : Sebuah Kajian Awal Interaksi Antara M Oney Politics And Electoral Dynamics In Indonesia :," 2013, 41-57.
} 
to elaborate on models of clientelism and social consequences that often negate voters' impact.

Methodologically, this research uses a descriptive-analytic approach. This research model analyzes the description of data, information, and events systematically, factually, and accurately using data in the form of words or statements from informants. The researcher conducted in-depth interviews to obtain accurate information. In this case, the researcher and informant's relationship is more flexible and reflective.

Moleong, an author of social research methods, explains that researchers and subjects in qualitative research have merged and now appear with little distinction (1995: 9). This assumption presupposes social closeness, empathy, and trust built during the data collection process. To obtain adequate information about the practice of money politics, the researcher became directly involved in the informants' social activities, especially during the campaign period in the 2019 general election in Glenmore District, Banyuwangi, East Java.

The researcher and the informant's familiarity were built through a participant observation pattern. This means that the researcher and the informant are in a common understanding to provide answers in extracting the information required by qualitative research. Therefore, the researcher had to comprehend the informant's background, such as language, culture, customs, and social habits that appear in the research object's daily activities. The goal is that researcher is accepted into the community while collecting the necessary data.

\section{CLIENTELISM, BROKERAGE, AND MONEY POLITICS IN GENERAL ELECTIONS IN INDONESIA}

According to Keefer, the institutionalism approach can be used to comprehend the Patron-client culture in a country. This approach considers political institution design in a country and its power to influence the rampant patron-client culture ${ }^{3}$. For example, the political competition in multi-party general elections, such as in Indonesia, are one of the causes linked to the rise of political patrons in general elections, decentralization, and decision-making processes in both the legislative and executive branches Muhtadi.. The existence of money politics in general elections also has consequences for the emergence of transaction cost politics in the political contestation process in a democratic system.

The study of clientelism in political science started in the 1970s as part of Susan C. Stokes initial wave of clientelism study, which was associated with the historical period of decolonization of nations in developing countries ${ }^{4}$. Even Brinkerhoff and

\footnotetext{
${ }^{3}$ Burhanuddin Muhtadi, "Politik Uang dan Dinamika Elektoral di Indonesia: Sebuah Kajian Awal Interaksi antara 'Party-ID' dan Patron-Klien” 10 (2013): 41-58.

${ }^{4}$ Diego Abente Brun dan Larry Diamond, Clientisme Social Policy and the Quality of Democracy (Baltimore: John Hopkins University Press, 2014).
} 
Goldsmith ${ }^{5}$ stated that the patron-client is an informal system that destroys democratic institutions, fosters money politics and corruption practices, and contributes to the inefficiency of bureaucracy and public services'. However, factually, if we pay attention to the emergence of party politics at the beginning of Indonesian independence, the emergence and the development of democracy developed from a party system based on clientelism ${ }^{6}$. as such, it is interesting to discuss how Indonesia's democratization process was formed and adapted to the local culture that displayed a different sociological character to the democratic tradition in Western countries.

The post-1998 period was known as the Reform Era, it represented an ironic condition of the early spirit of reform in Indonesia. The desire to strengthen nationalism, especially for freedom from corruption, which was strongly ingrained in the New Order regime, failed. Corruption practices were still evidently occurred during that era. The practice of corruption seemed to reinforce the nuances of clientelism in Indonesia's socio-political structure ${ }^{7}$. The corruption praxis, involving large political parties that are members of the government coalition, exploited the State Budget to strengthen their party networks. Corruption funds were primarily used for selfenrichment. Further, the multiplication of corruption funds was carried out by providing projects and assistance to supporters, strengthening the party's position in society. Through this, corruption is transformed into transaction politics.

Transaction cost politics refers to the costs incurred throughout the general election process. In this case, the cost component consists of the pre-election cost, during the election, and post-election $\operatorname{cost}^{8}$. Besides the patron-client culture and the weak political institutions, the emergence of prohibitive transaction cost politics rule in election for political parties indicated corruption practices. Those lead to the misuse of state and regional budgets.

High political expenditure by political actors during the general election process raises questions about whether a politician is capable of fighting for the community's interests when he/she is elected. Notwithstanding, politicians must cover considerable political costs throughout the general election process. Patron-client culture and high transaction cost politics do not work independently, they are mutually reinforcing and build reciprocatory bonds between patrons and clients, establishing symbiosis in the political market. These behaviors make transaction cost politics expensive. The relationship between politicians and electors continues after voters cast their votes during general elections. If a political actor is elected as a member of the legislature the politician will provide rewards in the form of policies and assistance,

\footnotetext{
${ }^{5}$ Derick Brinkerhoff dan Arthur Goldsmith, Clientelism, Patrimonialism and Democratic Governance: An Overview and Framework for Assessment and Programming (USA: Abt Associates Inc, 2002).

${ }^{6}$ Edward Aspinall dan Ward Berenschot, Democracy For Sale, Elections, Clientilism, and the State in Indonesia (Itha: Cornell University Press, 2019).

${ }^{7}$ M. Arief Amrullah, "Korupsi, Politik Dan Pilkadal Dalam Perspektif Pemberantasan Korupsi Di Indonesia," Syiar Hukum : Jurnal Ilmu Hukum 11, no. 3 (2009): 283-95, https://doi.org/10.29313/sh.vlli3.549.

${ }^{8}$ Alfira Sofia dan Budi S. Purnomo, "Evaluation of Election Cost-Value for Money Based Toward Good Government Governance" (3rd International Seminar and Conference on Learning Organization, Atlantis Press, 2016), 126-31, https://doi.org/10.2991/isclo-15.2016.24.
} 
funded by grants from the government budget, through the network of people's aspirations.

Transaction costs politics, in this case, are political transactions that occur in the policymaking process (public policy), both in explicit and implicit agreements (transactions) that exist between policymakers ${ }^{9}$. This is often followed by the manipulation of public policies to achieve their desired goals. Literature on the political economy, generally assumes that the government, politicians, or bureaucrats are rational agents in determining public policy direction. As such, a politician is expected to maximize their chances of getting and maintaining power by following through with their ideological and economic interests ${ }^{10}$.

Political actors have their own goals and interests. They act by considering the pros and cons of what they do ${ }^{11}$. Their actions are mostly motivated by short-term interests, without concern for long-term consequences ${ }^{22}$. The dimension of instrumental rationality produced by political actors is considered a factor in the emergence of the public choice approach ${ }^{13}$. The public choice approach is also known as rational choice, which seeks to analyze political actors' actions, including the legislative, executive, presidential institutions, electors, and others ${ }^{14}$. This theory places individual actors at the centre of analysis to explore various state roles and institutions whose positions are obtained through election or by appointment.

In Indonesia politics, where the community is focused, the political parties, government, and bureaucrats correspond with one another. The society acts as a buyer of public goods and can be formed through collective action, while the government and political parties become providers of these public goods. Through the provision of public goods, they expect public support (voters) in the general elections. In the context of this mutually beneficial relationship, financial ratios are exchanged through the political market where state life becomes commodified.

At the level of analysis, public choice theory is divided into two categories. The first theory is normative public choice theory. The focal points of this theoretical study are issues related to design and basic political rules. This theory is related to the constitutional framework that underpins political processes. The second theory focuses

\footnotetext{
${ }^{9}$ Norman Schofield, Gonzalo Caballero, dan Daniel Kselman, ed., Advances in Political Economy: Institutions, Modelling and Empirical Analysis (Berlin, Heidelberg: Springer Berlin Heidelberg, 2013), https://doi.org/10.1007/978-3-642-35239-3.

10 Witold Henisz dan Bennet Zelner, "Explicating Political Hazards and Safeguards: A Transaction Cost Politics Approach," Industrial and Corporate Change 13, no. 6 (2004): 901-15, https://doi.org/10.1093/icc/dth036.

${ }^{1 l}$ Pramudya A. Oktavinanda, "Public Choice Theory Dan Aplikasinya Dalam Sistem Legislasi Indonesia (Public Choice Theory and Its Application in Indonesian Legislation System)," SSRN Scholarly Paper (Rochester, NY: Social Science Research Network, 8 Oktober 2012), https://doi.org/10.2139/ssrn.2158542. ${ }^{12}$ Omar Ahmed Abenza, "The Public Choice Theory, and Its Capacity to Explain Unpopular Nationalist Policy Decisions," Public Choice 106, no. 1 (2001): 1-6.

${ }^{13}$ Ahmad Erani Yustika, Krisis finansial, kontestasi politik, dan prospek ekonomi 2009: proyeksi ekonomi Indonesia, 2009, ed. oleh INDEF (Organization) (Jakarta: INDEF, 2008).

${ }^{14}$ Didik J. Rachbini, Ekonomi politik: paradigma dan teori pilihan publik (Ghalia Indonesia, 2002).
} 
on political behavior that can be observed in the form of choice ${ }^{15}$. This political theory is also known as the positive political theory, which works in the real world (das Sein).

Public policy becomes a problem in transactional political systems where corruption and money politics are the determinants. The existance of political parties' is a necessary requirement for the formation of a healthy democratic society. Withinn this climate it is expected that public policy is formed through constructive and egalitarian dialogue. However, rates of corruption in Indonesia demonstrates that democratization is a political process that is continuously overshadowed and undermined by corruption ${ }^{16}$.

\section{The Clientelism of Kiai-Santri and General Models of Money Politics Practices}

To portray the Clientelism of Kiai-Santri and money politics practices in the 2019 General Election in Indonesia, the case study of General Election in Glenmore District, Banyuwangi Regency, East Java, Indonesia becomes an exciting example to discuss. Realistically, the political journey in Glenmore District cannot be separated from the political activities of the Nahdatul Ulama (NU) people, who are recorded in the political history of the Glenmore District. Parties supported by the people of NU dominate vote acquisition in every election activity in the Glenmore District after the Reformation.

The involvement of the religious elite or Kiai in the General Elections can be seen through political jargon "Santri follows the Kiai's choice". The involvement of NU citizens in politics was part of Kiai's obligations as ulama to preach in politics. Furthermore, for Kiai, politics was a da'wah area that would benefit the community greatly.

To discover relational schemes in the practice of clientelism, the Kiai-Santri role played by the Pesantren community. In the general election, this could be traced through the Kiai's involvement to take advantage of their social position to influence the choices of NU residents. Although the model of involvement in politics was practically different when compared to the New Order era. Consequently, two young Kiai in Glenmore - Partai Kebangkitan Bangsa and Partai Persatuan Pembangunan failed to become members of the Banyuwangi Regional People's Representative Councils (DPRD) for the 2019-2024 period, even though both were nominated from parties with Islamic Party backgrounds.

In the 1999, 2004, and 2008 general elections, the Kiai in Banyuwangi appeared to be directly involved in the political arena and promoting political cadres who would become members of the DPRD or fill executive positions in government. Ideological

\footnotetext{
${ }^{15}$ James A Caporaso dan David P Levine, Theories of Political Economy (USA: Cambridge University Press, 1992).

${ }^{16}$ Muhammad Aqil Irham, "Korupsi Demokratis dalam Partai Politik: Studi Kasus Penyelenggaraan Pemilukada Lampung," MASYARAKAT: Jurnal Sosiologi 21, no. 1 (4 November 2016): 35-56, https://doi.org/10.7454/mjs.v2lil.4799.
} 
reasoning was used in an attempt to legitimize the Kiai's involvement in placing the best cadres of NU, especially those affiliated with parties labeled traditional Islam. They volunteered to act as vote gathers. Meanwhile, legislative or executive candidates became agents by playing da'wah's issue as a central issue in mobilizing the masses in general elections.

The failure of candidates from pesantren parties to become legislative members in the 2019 elections could be explained as the result of legislative candidates's behavior from Islamic boarding schools that still applied a cultural ideology to approach the voters. Despite having made use of the pesantren curricular network or the structural and cultural network in Jam'iyah Nahdlatul Ulama, the cultural solidarity used by the two candidates no longer appeared equal to the patterns of political games played by non-pesantren politicians. Although not a part of cultural parties that have ties to the Jam'iyah Nahdlatul Ulama, the elected candidate could harness their financial power to influence pragmatic voters. In the context of Indonesian politics, voter pragmatism is understood as a labour arket of politics. Voters expect material benefits in return for their participation in elections and casting their vote for particular politicians.

The 2019 general election represented a dramatic change in this relationship pattern. Previously, the Pesantren network and Kiai's power were used to gether votes. However, they were replaced by local political brokers who were not directly related to the pesantren and Jam'iyah Nahdlatul Ulama. Some brokers were not even cadres of the political parties that carried the legislative candidates. They came from various backgrounds and often did not understand the ideology of the political party their legislative candidates represented.

Independent political actors were looking for shortcuts to mobilize the masses through money politics. Kiai was no longer a character that could link the party's struggle with NU's citizens' interests. Legislative candidates only came to Kiai to ask for blessings and prayers for their success in general elections. Kiai and Pesantren also appeared to be open to the presence of legislative candidates. They were willing to give their blessings and prayers to political elites who came to the Islamic boarding schools. In this passive position, Kiai often got the political elites' promise for giving the aid projects for Islamic boarding schools once they became members of the Regional People's Representative Council or occupied certain positions in the government.

Political elites in certain positions were granted full political freedom previous communication with Voters through the concessions in the form of grants. The presence of incumbent legislative candidates was easy to accept because they were armed with concrete evidence of grants made to the community. From the researchers' observations, legislative candidates in the 2019 election tried to take advantage of the existing communication channels to gain voters' sympathy in the general election.

The interviews process found several practices of Money Politics in the general election that were carried out by using the following models. First, a politician came to the Islamic boarding school to introduce themself and ask for blessings on his nomination as a legislative candidate. Once he had to leave, he gave a package and sum 
of money to Kiai. The candidate often explicitly asked for blessings that concretely wanted the Kiai to mobilize the Santri to elect him. This research also found that some legislative candidates dared to promise a nominal value of money amounting to tens of millions of rupiah if they were elected as a member of the Regional People's Representative Council.

Second, the candidates for legislative members also used the provision of material benefits to prospective voters. This included pledges to assist developing pesantren and existing educational institutions in pesantren. These finances were obtained from the government funds. In practice, legislative candidates prioritized aid proposals originating from their constituencies. Alternatively, some legislative candidates could provide gifts directly to Islamic boarding schools and the Santri in their respective regions. The gifts were mostly in the form of veils, sports equipment, or building materials initiated by the legislative candidates.

Third, another way they used was transparent vote-buying. Through the practice of vote-buying, the transaction cost politics developed into the most expensive cost component. To do buy-and-sell votes, the candidate had to provide IDR 50,000 per household. This would soon be given at several points in the electoral district. Some incumbents dared to offer a more considerable amount of IDR 50,000 per person. This term is popularly known as Tongket ${ }^{17}$ (Settong Seket). In Madurese, Settong means "one person," while Seket means IDR 50,000.

This pattern of voice buying is used in a variety of ways. One relatively new mode involves the giving of money with a payable agreement. According to one legislative candidate's admission, who applied this model, this method is an excellent way to avoid election violations. Legislative candidates took advantage of the presence of local brokers. The research showed that a broker could handle about 20 potential voters. Later, the legislative candidates would give a sum of money to the brokers, approximately IDR 2,000,000 for every 20 voters, with a payable agreement. If he were elected, he would be promised a higher return to repay the debt.

However, there was no factual agreement and debt repayment mechanism. The money was only utilized to buy the votes of 20 people. Therefore, job broker was only tasked with the distribution of money to the 20 targeted voters. Usually, this kind of model is based on the Voting Place. As the principal who desired the higher votes, legislative candidates would give the brokers a bonus based on their target's voting numbers. For example, if the vote acquisition follows the promised target, 20 people, the bonus will be calculated as IDR 50,000x20 people. So, the broker will receive a bonus of IDR 1,000,000 (one million rupiahs). The vote-buying mode in Banyuwangi's general election 2019 was relatively new and has not been a feature of previous elections.

\footnotetext{
${ }^{17}$ The term Tongket appears in the Glenmore society ahead of the general election, or Village Head election, which implies that they will elect the candidate if they are rewarded IDR 50,000 per person. Tongket stands for "Settong Seket" which means One Voice is rewarded IDR 50,000.
} 
An exciting observation made in this study is that brokers no longer need to have a similar ideology with the candidates they supported in carrying out their duties. Moreover, some brokers were able to make agreements with legislative candidates across political parties. The broker called it a package system; for example: in the Regional People's Representative Council election, he worked for Candidate Number 1 in Party A; then for the Provincial People's Representative Council level, he works for Candidate Number 9 in Party N; and at the Republican People's Representative Council level he worked for Candidate Number 4 in Party Z.

In addition to the multi-party package model, there was also a one-party package mobilization model, which ensured a supporting pattern of legislative candidate packages from each level of the same party. This kind of support mobilization model was the most widely used model due to its cost-effectiveness for the political candidates. In this kind of model, a person who often acted as a broker was a figure or cadre of a local political party of the legislative candidates for the Regional People's Representative Council. From the broker's social position, were believed to have an emotional connection to voters which could be exploited to gain the financial benefits linked to the particular candidacy.

In some cases, brokers were not from legislative candidates, but had social positions that could influence other people's political choices. Further, the researcher found that a legislative candidate for the People's Representative Council of the Republic of Indonesia from a party that was part of the government coalition holding a legislative candidate for district-level elections from an opposition party. Such local coalition relationships were not based on differences in ideology and interests at the national level but prioritizing the opportunity of electability and utilization of social networks at the mass base level.

Fourth, the use of grant funds through the assistance of Community Aspirations Network (Jasmas). It would be easier for the incumbent legislative candidates to gain public sympathy rather than newcomers who had no social investment in the community. Three out of five members of the Banyuwangi Regional People's Representative Council, who came from Glenmore District, were re-elected. Crucially, though, this study is not intended to accuse the incumbent of using grant funds as a political instrument.

The relationship between politicians as incumbent legislative candidates, brokers, and voters during the pre-election period became increasingly intimate through the government assistance policies, which legislators usually proposed through the grant concession, Jasmas $^{18}$ (Community aspirations network), given to voters through brokers. The emotional closeness of the incumbent legislative candidates

\footnotetext{
${ }^{18}$ Jasmas (Community Aspirations Network) is assistance from the government through the State and Regional Budgets, provided to community groups through legislative members, either at Regional House of Representatives, Provincial House of Representatives, or the House of Representatives of Republic Indonesia. Usually, each member of the legislature is assigned a certain amount in each electoral district. The purchase value of the material is different, adjusted to the legislative member's position in their respective institution.
} 
became their strategic position as legislative members who had the proposed grant aid policy package. These concessions did not run naturally but had specific purposes and objectives used by the incumbent to benefit their candidacy in the future.

Observing the pattern of reciprocity relations between legislative candidates as Principals and the electors as agents, the presence of political brokers in the political realm in the context of social capital theory and public choice theory seemed relatively straightforward. Primarily by predicting the relationship between these three political elements to build cultural, political, and economic power in the community. The principals and agents are rational actors whose goal is to benefit their group.

In line with this, the author described how the clientelism model was built and fosters corrupt practices through grant funds. The delivery of grants or material gifts from political elites to religious leaders in their respective regions was a form of caring. This shows that the elite and the community were still connected. This relationship would continue to help the elite in their future political aspirations relating to reelection.

However, cooperation between politicians and brokers often misused this concession by collecting a certain percentage of the aid projects' value for themselves. Law enforcement officials noticed this kind of direct reduction from the project's value and this caused the new pattern of providing social assistance. In the new method, members of the legislature who would help disburse the grants received the community's proposals through party officials in the regions.

The informants stated that the proposals were usually submitted orally first. If the community institution's name appeared as a potential beneficiary, it would be asked to propose an activity proposal. Like the need for the disbursement of aid funds, beneficiaries are asked to formally open a bank account and transfer it over to the people who assumed the position of aid coordinators. In this second mode, they are not based on a certain percentage of the project value. However, legislature members have appointed party cadres as third parties to provide the items referred to in the proposal submission. This method usually has legislative third party.

\section{CLIENTELISM AND PRACTICAL POLITICS}

The religious elite mostly played the patronage that existed in the post-reformation era. Primarily relating to the strengthening of identity politics that emerged with the formation of political parties based on post-reform ideologies. However, in the 2019 election, the patronage relationship between religious elites was largely displaced by the emergence of local political brokers who acted as intermediaries between politicians and voters.

This condition was mostly caused by internal conflicts in religious-based parties, such as Partai Kebangkitan Bangsa and Partai Persatuan Pembangunan. Many pesantren Kiai circles consequently chose not to involve themselves in future party politics. This was underlined by the problem of maintaining popular unity. The existence of conflicts and divisions in political parties and party elites' involvement in 
several corruption cases has reduced public trust in religious elites at both local and national levels.

The 2019 legislative election that coincided with the President and Vice President's election attracted Kiai's attention, who affiliated with Nahdlatul Ulama. They more enthusiastic to the success of the Presidential and Vice-Presidential candidates they supported. Moreover, one of the vice-presidential candidates was a Kiai, precisely the Rais of Syuriah PBNU. Pesantren politics in Banyuwangi represented the party contestation issue in winning over the people's votes and maintaining NU's cultural legitimacy through representation in the presidency.

Beyond the Islamic political issue, clientelism and political brokerage must also be reflected on, especially in the context of voice commodification. In general, the patterns and modes in the vote-buying system use a contractual model. In a study with a business administration dimension, Vardy and Morgan researched the contractual model of buying and selling votes ${ }^{19}$. They argued that voters' primary concern lies in the material and financial benefits they receive rather than ideological issues or commitments. In the contractual model that was carried out in the 2019 general election process, several schemes existed, both promised policies after they were elected, contractually, individually, or in groups directly before voting took place, either in the form of money or goods. It is common for politicians to practice vote-buying in the contractual form by signing political contracts.

Political contracts are generally constituting political promises in a vision and mission that politicians will carry out after being elected as political officials in either the legislative or executive. There is also a political contract model made by voters or pressure groups that are presented to politicians in exchange for political support in general elections. However, in practice, these two things are closely intertwined with one another, especially to create loose political relations between parties and others. In carrying out the practice of buying and selling votes, legislative candidates did not have many options other than taking advantage of brokers' presence. In this case, the brokers emerged from local figures, including the relatives of legislative candidates, who had to distribute funds and goods to their constituents.

The variety of Indonesia's political activities and the formal institutions' powerlessness to enforce the rule of law has prompted electors to sell their votes. This problem should not be understood as an issue of voter conscience. Rather, it should be considered within the social context and structure that has enabled individuals to gain benefit from selling their vote. Such conditions brought about the powerless pesantren and other social institutions in the economic field to ultimately fall into practical politics traps.

"Political grants" became a strategic way forming reciprocity relationships between the public and politicians. Some grant aid projects are programs designed collectively between the legislature and the executive (principal) by utilizing the

\footnotetext{
${ }^{19}$ Felix Várdy dan John Morgan, "Corruption, Competition, and Contracts: A Model of Vote Buying," IMF Working Papers 06, no. 11 (2006), https://doi.org/10.5089/9781451862713.001.
} 
agents (voters) in need of assistance with issues shared between the principal for particular political interests. This commonly happened during the end of the principal's office term, ahead of general elections.

The actors' behavior associated with the political activities described how each actor behaves as described in rational choice theory. This assumes that social activity conforms to the principle of Utility Maximization, a concept borrowed from microeconomics. From this, politicians, brokers, and voters are rational actors are expected to act selfishly to maximize their actions' utility.

A politician may sacrifice his financial resources to increase his power. To achieve that goal, he needs supporters from the community (voters). Through comprehensive coverage and many voters, a politician needs an intermediary (broker) to link the political actors' and voters' desires. A broker as an extension of the politician (principal) in working is also inseparable from his motivation to get the maximum benefit, either individually or in groups, in his environment. The desired benefits can be personal or communal. As such, the purpose of his involvement in politics is also to obtain grants from the government for a common goal.

Voters believe that the politicians' desire to achieve political goals depends on their votes in the general election. The personal motivation of voters to seek personal gain also contributed to the emergence of money politics or vote-buying. Voters' can exchange their votes for money or material needed from the politicians during the general election period.

Voters are often seen as an abstract concept. Once the politician is elected to a political position, in either the legislative or executive branch, it will not change or affect the voters' daily lives. Therefore, the provision of material in the general election process is considered fair in relation to the votes cast. A politician who holds a political function will enjoy his position with exclusive facilities and social status for five years.

The rent-seeking process does not end with the general election. The politicians who are elected as legislators change their symbiotic relationship. The symbiotic relationship between principal-agents shifts when politicians share government projects through grants from the Community Aspirations Network. Each of the principals and agents continues to seek personal advantage throughout this process. The principals are fully aware that their Political Transaction Cost expendature will reduce their savings. Thus, they begin to seek financial and political benefits for the next election through grant aid projects.

\section{THE DARK SIDE OF DEMOCRATIC PRACTICE}

Based on the description above, it can be seen that even though, in some cases, there was a transformation of clientelism praxis in the religious elite into the emergence of non-religious elite political brokers, clientelism remained the dominant factor accompanying the implementation of general elections in Indonesia. Another issue is related to sanctions made by the government that were not received well by political actors and triggered the emergence of new patterns of money politics. This showed that 
the institutional governance of election administration was still weak in enforcing the game's rule. Furthermore, the election organizers were still unable to carry out regulatory functions and punishment in the administration of elections.

Apart from the cleft of the governance and rules in the implementation of elections in Indonesia, election participants' weakness of supervision in the electoral process became a separate note in this study. Political parties failed to carry out the function of cadre recruitment in Indonesia because of the failure to recruit party members on an ideological basis opened space for the inclusion of profit-seeking individuals. This condition made the competition in becoming a member of the legislature became a high-cost vote market mechanism that contributed to the emergence of a Political Transaction Cost, which was very burdensome for politicians and triggered corruption.

\section{Conclusion}

The post-Soeharto reform created a new political system that marked political liberalization as an inevitable condition-a shared desire to improve the socio-political situation in Indonesia. A multi-party system emerged in Indonesia with the post-1998 elections resulting in fierce electoral competition for public support. Simultaneously, the limited number of political positions both in the legislative and executive branches gave birth to the practice of Money Politics, which resulted in prohibitive political costs of getting to political power.

Like many previous elections, the 2019 General Election was characterized by the practice of money politics. Meanwhile, clientelism relationships continued to influence the practice of money politics in general elections, despite experiencing change with the emergence of political brokers from local elites who had a strong influence in their environment.

In the context of the institutional economy, clientelism, which constructs the emergence of money politics praxis in Indonesia, is an issue that will continue to be discussed in its local variants. Where funding for political parties is still weak and inefficient, political transaction costs are high. This provides space for the continuation of corruption already embedded in existing political institutions. Therefore, it is essential to design the institutions with rational governance to ensure effective and efficient election implementation.

The Banyuwangi election is just one example of the many problems of democracy faced by Indonesia. Social inequality and its impacts on practical political articulation are serious issues for the electoral process. Political pragmatism is no longer an issue that can be approached through the lens of religious or social group identity. Rather, it should be understood as an issue rooted in fragile institutional governance, both in the formal and social institutions that develop in society. These two institutional characteristics are a crucial part of the foundation of Indonesia's maturity in developing its democratic model. 


\section{ACKNOWLEDGMENT \\ None \\ COMPETING INTEREST}

None

\section{REFERENCES}

Abente Brun, Diego, dan Larry Diamond. (2014). Clientisme Social Policy and the Quality of Democracy. Baltimore: John Hopkins University Press.

Abenza, O. A. (2015). The Public Choice Theory, and its capacity to explain unpopular

Nationalist policy decisions. Global Diplomacy - 'Global Public Policy,' August, 1-6.

Aminuddin, M. Faishal, dan Natasha Hassan Attamimi. (2019). From Retail to Grocery: Money Politics in 2014 Indonesian Legislative Election. Politik Indonesia: Indonesian Political Science Review 4, no. 1: 99-120. https://doi.org/10.15294/ipsr.v4il.12609.

Amrullah, M. A. (2009). Korupsi, Politik dan Pilkada dalam Perspektif Pemberantasan Korupsi di Indonesia. [Corruption, Politics And Pilkadal In The Perspective Of Corruption Eradication In Indonesia] Syiar Hukum, 11(3), 271-283.

Aspinall, Edward, dan Ward Berenschot. (2019). Democracy For Sale, Elections, Clientilism, and the State in Indonesia. Itha: Cornell University Press.

Brinkerhoff, D., \& Goldsmith, A. (2002). Clientelism, Patrimonialism and Democratic Governance: An Overview and Framework for Assessment and Planning.

Caporaso, J. A., \& Levine, D. P. (1992). Theories of Political Economy. Cambridge University Press.

Diego Abente Brun, L. D. (Ed.). (2014). Clientisme Social Policy and the Quality of Democracy. John Hopkins University Press.

Edward Aspinall, W. B. (2019). Democracy For Sale, Elections, Clientilism, and the State in Indonesia. Cornell University Press.

Henisz, W. J., \& Zelner, B. A. (2004). Explicating political hazards and safeguards : a transaction cost politics approach. 13(6), 901-915. https://doi.org/10.1093/icc/dth036

Irham, M. A. (2016). Korupsi Demokratis dalam Partai Politik: Studi Kasus Penyelenggaraan Pemilukada Lampung. [Democratic Corruption in Political Parties: A Case Study on the Implementation of the Lampung Pemilukada] MASYARAKAT: Jurnal Sosiologi, 21(1), 35-56.

M. Faishal Aminuddi, N. H. A. (2019). From Retail to Grocery : Money Politics in 2014 Indonesian Legislative Election. Politik Indonesia: Indonesian Political Science Review, 4(January), 99-120.

Muhtadi, B. (2013). Politik Uang Dan Dinamika Elektoral Di Indonesia : Sebuah Kajian Awal Interaksi Antara M Oney Politics And Electoral Dynamics In Indonesia. [Money bPolitics And Electrical Dynamics In Indonesia: An Initial Study Of Interaction Between M Oney Politics And Electoral Dynamics In Indonesia] 41-57. 
Muhtadi, B. (2013) "Politik Uang dan Dinamika Elektoral di Indonesia: Sebuah Kajian Awal Interaksi antara 'Party-ID' dan Patron-Klien” [Money Politics and Electoral Dynamics in Indonesia: An Early Study of the Interaction between 'Party-ID' and Patron-Client]. 10: 41-58.

Oktavinanda, P. A. (2012). Public Choice Theory dan Aplikasinya dalam Sistem Legislasi Indonesia. [Public Choice Theory and Its Application in Indonesian Legislation System]. 1-24.

Prihadi, S. D. (2015). YouTube dalam Angka-Angka. CNN Indonesia. https:/www.cnnindonesia.com/teknologi/20150214143544-185-32127/youtubedalam-angka-angka

Rachbini, D. J. (2002). Ekonomi Politik: Paradigma dan Teori Pilihan Publik. [Political economy: paradigms and theories of public choice] Ghalia Indonesia.

Schofi, N., Daniel, C., Editors, K., Schofeldi, N., \& Caballero, G. (Eds.). (2013). Advances in Political Economy. Springer. https://doi.org/10.1007/978-3-642-35239-3

Sofia, A. (2015). Evaluation of Election Cost-Value for Money Based Toward Good Government Governance. Isclo, 126-131.

Várdy, Felix, dan John Morgan. (2006). Corruption, Competition, and Contracts: A

Model of Vote Buying. IMF Working Papers 06, no. 11. https://doi.org/10.5089/9781451862713.001.

Yustika, A. E. (2008). Krisis Ekonomi, Kontestasi Politik, dan Proyeksi Ekonomi 2009. [Financial crisis, political contestation, and economic prospects 2009: Indonesia's economic projections, 2009.] Disunting oleh INDEF (Organization). Jakarta: INDEF. 